\title{
Cultural Awareness through Animal Proverbs in English and Myanmar
}

\author{
Thet Ni
}

\begin{abstract}
Every country has proverbs that are unique to it. Proverbs reflect the culture of people and its nation. Proverbs and sayings are effective devices of truth about culture, religion, tradition, custom and belief. The present study tries to find out the cultural differences in the concept of animals through English and Myanmar proverbs.Animals have been in harmony with human beings through centuries. People have used animal images in their daily livesto express their ideas and feelings explicitly. There are lots of animal proverbs in English and Myanmar but this study compares and analyzes some proverbs which are identical in meaning but are different in animal images and proverbs with identical in meaning and animal images.For this purpose 11 proverbs from English and Myanmar are collected and analyzed. It is identified that some proverbs share similar semantic function with different animal images. These proverbs reflect different cultural, social and cognitive values of two nations.
\end{abstract}

Index Terms - Myanmar, English, Proverbs, Culture, Animal.

\section{INTRODUCTION}

Proverbs have been used in languages in the world for centuries. Proverbs are related to history, politics, cultures, religion and tradition of their own countries. Among proverbs, animal proverbs are distinctive to describe human beings figuratively. Different languages use different animal images in accordance with their respective culture. The behavioral traits, personality qualities and attitudinal reactions of human beings are considered animal like. People interpret animal behavior or other attribute based on cultural aspects and social experience. Proverbs are used to illustrate the point, to make eloquent speeches and to engage in lively conversations.

\section{A. Objectives of the study}

This study aims to explore the social cultural values through animal proverbs and to analyse the similarities and differences of animal expressions denoting human characteristics.

\section{B. Definitions of proverb}

A proverb (from Latin: proverbium) is a simple, concrete, traditional saying that expresses a truth based on common sense or experience. Proverbs are often

Thet Ni, Lecturer, Department of English, East Yangon University, Myanmar metaphorical and use formulaic language. Collectively, they form a genre of folklore. (Wikipedia)

Proverbis a short saying in common and recognized use: a concise sentence, often metaphorical or alliterative in form, which is held to expresssome truth ascertained by experience or observation and familiar to all .( The Oxford English Dictionary)

Saeed( 1997: 15) states that in most cases, proverbs are used figuratively because their meaning is interpreted differently from its literal meaning.

Mieder (2004:3) defines proverb as "a short generally known sentence of the folk which contains wisdom, truth, moral and traditional views in a metaphorical and memorable form and which is handed from generation to generation."

\section{Geographical and cultural background}

As Myanmar is situated in South East Asia and possesses tropical and subtropical climates, agriculture is the back-bone of its economy. As a result of being a traditional agricultural society, most Myanmar proverbs, songs, stories, etc. have been composed about the cultivation of rice and crops.

Moreover in the past, most people lived in rural areas where farming was their main occupation and animals took part an important role in people's lives. They have raised cows and buffalos for food, transportation and labour especially in paddy cultivation. For example, Myanmar proverbs like "To put the harrow before the cow" and "Playing a harp before a buffalo", use farm animal images, "cows and buffalos" which Myanmar farmers wholly depended on in their cultivating process.

On the other hand, the weather in England is quite different form Myanmar. If has got temperate climate with mild summers and winters. It possesses a series of rolling hills, undulating low lands and fields. For farming, cows and sheep are normally specialized for wool, milk and meat. It is said that historically, England economy depended on sheep breeding and sheep can be considered as the most popular cattle to the English. For example, English proverbs like "Death devours lambs as well as sheep" and "Old sheep shouldn't dress in lamb's fashion" are about sheep.

\section{Cultural Identity}

Each country has its own cultural identity which is influenced by several factors such as religion, language, nationality, ethnicity social class and so on. This cultural identity has great effect on the people and their language. Therefore, understanding proverbs in two languages gives us 
a deeper insight into sociocultural contexts of these two nations.

Traditionally, most Myanmar people practise Buddha teaching and philosophy which have influenced the way of life and culture. Myanmar proverbs reflect social, moral and religious contexts of people'slives. According to Myanmar culture, most peopleconsider animals as inferior, unintelligent and ungrateful ones and this concept can easily be seen in Myanmar proverb like "A dog sleeps on leather and gnaws the edges". However English men have different view on the same animal. They consider dogs as royal, grateful, strong, brave and noble animals. The proverbs like "A live dog is better than a dead lion" and "As the old dog barks,so the young one" reveal this concept.

\section{RESEARCH METHOD}

The analysisof the proverbs in this study is carried out with qualitative approach. The English data are collected from the book , "English Language Toolbox : Proverbs", reference books, literature, internet and specific sources which study proverbs while Myanmar data are selected from"Burmese Proverbs" by DrHlaPe, "Myanmar proverbs and sayings", by HlaThamein and Pyinnyarkyaw and other associated books, articles and journals. To get more specific information oral data collection from daily life conversations are also applied. The analysis of proverbs in thisstudy applies the concept of reading and analyzing literature that concern with the relationship between literature , social and cultural context. This concept is influenced by a French scholar named GèrardGenette (1999) who proposed in late $20^{\text {th }}$ Century, that in order to read and truly understand literature, and despite the primary focus on the text itself, one should study to understand the work of the writer who lives and exists in the society and culture that breed him. The origin ofsome animal proverbs, their usage and the sociocultural backgrounds have been analysed and categorized astwo categories. The first type includes animals which are identical in animal images but different in meanings and the second type includes animals which are identical in both in animal images and meanings.

\section{ANALYSIS OF ANIMAL PROVERBS IN ENGLISH AND MYANMAR}

England and Myanmar are countries of history and tradition. Both countries can boast their culture, tradition, custom and language which have flourished over centuries. Though they possess different cultural backgrounds locating in the east or west, they share the same view or feeling towards the world. They express their feelings, ideas or beliefs using animal images in their daily life conversations, at work or in business. There are many proverbs which include animal images in both languages. But this paper tries to analyse some animal proverbs which are identical in meanings but different in animal images and proverbs which are identical in both animal images and meanings. Data analysis and interpretation of someselected proverbs is as follows.

\section{A. Identical in animal images but different in meanings}

a. To put the cart before the horse.(English)

To put the harrow before the cow.(Myanmar)

They mean that people should not do things in the wrong order. According to Wikipedia, they suggestthat something should not be done on contrary to a conventional or culturally expected order or relationship. In Myanmar, this proverb is used when the elders or parents suggest their younger ones who have less experience to do thingsin order or hieratically.

\section{b. If you run two hares, you will catch neither (English)}

Catch two fish at the same time (Myanmar)

Both languagessuggest to concentrate on one thing at a time or you will achieve nothing. Trying to do two or more things at a time, when even one is on its own needs full effort means that none of them will be accomplished properly.In Myanmar, this saying is used when people want to remind those who are paying attention to two thingsto obtain achievement in one business.

\section{c. To cast pearls before swine. (English)}

Playing a harp before abuffalo.(Myanmar)

These proverbs suggest that people should not waste good things on people who will not appreciate them. In other words, they mean that they should not offer something valuable or good to someone who does not know its value.

\section{d. Don't count their chicken before they hatch. (English)}

Look for the lime before one gets the hare. (Myanmar)

These proverbs advise people not to be sure that something for which they are hoping will actually happen because the outcome might be quite different and they will be disappointed. This proverb is used as a simile in Myanmar in a situation when people make unnecessary preparations before they don't see any outcome.

e. It's a foolish sheep that makes the wolf hisconfessor (English)

Falling down before the tiger(Myanmar)

These proverbs suggest that you should never confide in anyone unless you are sure that he will respect your confidence and will not turn to his own advantage what you have said to him.

\section{f. Never look a gift horse in the mouth (English)}

Don't examine the teeth of the cow one gets a gift (Myanmar)

They mean that if a person tries to check the teeth of the horse which was received as a gift then that means that instead of being grateful he was trying to find the value of the present and is a rude behaviour. It is seen as the person wants more even though a horse was quite a gift by itself. Myanmar people use this proverbto suggest that it is inappropriate to look for imperfection and complain about something that one does not need to pay for, just like examining the teeth of the 
cow one gets free to estimate the age.

\section{B. Identical in both animal images and meanings}

a. Bite the hand that feeds you (English)

A dogsleeps on leather and gnaws the edges (Myanmar)

They mean that people sometimes attack, harm, show ingratitude toward, or otherwise turn against someone who is helping them.In Myanmar concept, the meaning of this proverb is a personshould not behave like a dog which turns against its owner who provides food for it. These proverbs express that one should not do the behavior of ingratitude. So the concept of gratitude plays an essential role in Myanmar culture and it can be decisive factor to a person who is good or bad.

b. You can't teach old dog new tricks (English)

Teach the old doghow to shake hands(Myanmar)

They suggest that it is difficult to persuade older people to use new method, acquire new skills or try out new ideas. It isused as a social satire in Myanmar culture in the form of simile especially when people want to learn new skills when they are old, not active and cannot concentrate on learning.

c. The dog barks but the caravan goes on(English)

The dog barks but the hill does not move(Myanmar)

They mean that life goes on even if people or even try to stop you. In Myanmar culture, it is an advice to go on doing what you think is right for youin order to get success although people pull you down.

\section{d. A barking dog seldom bites (English)}

Don't be afraid of the dogs that bark all the time (Myanmar)

They mean that you should not be afraid of people who threaten you or who always say they will do something bad to you as they rarely take action.

e. When the cat's away, the mice will play (English)

Because the cat'saway, the mice are at play (Myanmar)

They mean that when someone in authority is not present, those whom the person is in charge will take advantage of the situation in some way, such as by playing or enjoying themselves instead of working. These proverbs are amazingly identical in both form and meaning.

\section{CONCLUSION}

Animals play an important role in construction of proverbs and are part of language, an indispensable element of culture. From the above analysis of animal proverbsin English and Myanmar, it is found out that animalproverbsshare the same cognitive processing based on the idea from human experience with animals. Proverbs are not only effective language devices which are sometimes used in the forms of metaphor or simile but also cultural carriers from generation to generation. It isstudied that animal proverbsin both languages reflect the similarities and differencesof culture, way of life, and way of thinking, religiousbeliefs, social values and worldview of two nations.
Other interesting issues have been found out that there are many other categories of English and Myanmar proverbs that have not examined from which a clearer understanding of two different cultures can be studied. Proverbs are inseparable parts of each country's language and culture and therefore this study might help the second language learners of Myanmar and English understand the use of proverbs in a particular contextand give the useful tools for translation from one language to another.

\section{REFERENCES}

[1] Betty Kirkpatrick MA ( 2003) English Language Toolbox: Proverbs. Singapore: Learners Publishing Pte Ltd

[2] Department of Education Affairs (2010) Myanmar Proverbs.Naypyitaw: Department of Myanmar

[3] GèrardGenette (1999) The Aesthetic Relation. Ithaca and London: Cornell University Press

[4] HlaPe, Dr. ( 1962) Burmese Proverbs. London: UK Press

[5] HlaTha Mein (2000) Myanmar Proverbs. Yangon: Time Lin Press

[6] HlaKyaw Nay ( 2009) 100 Proverbs with 100 Pictures. Yangon: Kant Kaw Myaing Press

[7] KhinMyoChit(1995) Colourful Myanmar. Yangon: Kalhya Press

[8] Mieder Wolfgang (2004) Proverbs A Handbook. London: Greenwood Press

[9] Pyinnyarkyaw(2009) Myanmar Proverbs and Sayings. Yangon: Unity Press

[10] Saeed, John I ( 1997) Semantics. Oxford: Blackwell.

[11] Speake, Jennifer ed. (2008).The Oxford Dictionary of Proverbs. $5^{\text {th }}$ Edition, New York, Oxford University Press

[12] Sperber, D, and Wilson D. (1995) Relevance: Communication and Cognition. Oxford: Blackwell 